\title{
Linkage analysis of a DNA polymorphism proximal to the Duchenne and Becker muscular dystrophy loci on the short arm of the X chromosome
}

\author{
CS BROWN, PLPEARSON*, N S T THOMAS, MSARFARAZI, PS HARPER, \\ AND D J SHAW \\ From the Section of Medical Genetics, University of Wales College of Medicine, Heath Park, Cardiff; and \\ ${ }^{*}$ the Department of Human Genetics, Sylvius Laboratoria des Rijksuniverseit, Leiden, The Netherlands.
}

SUMmARY The inheritance of a restriction fragment length polymorphism (RFLP) detected by a cloned DNA sequence (p754) from the short arm of the X chromosome has been studied in 14 Duchenne muscular dystrophy kindreds and six Becker muscular dystrophy kindreds. The linkage data obtained suggest that both the DMD and BMD loci are located in the same region (p21) on the short arm of the X chromosome at a distance of about 15 to $20 \mathrm{cM}$ from the 754 locus. Data from families informative for both the p754 and L1.28 polymorphisms suggest that p754 is closer to the disease loci than is L1.28.

Duchenne muscular dystrophy (DMD) and Becker muscular dystrophy (BMD) are $\mathrm{X}$ linked recessive disorders, DMD being the more severe and the commoner, occurring at a frequency of up to one in 5000 newborn males, with one third of all cases resulting from new mutations. ${ }^{1}$ BMD, first described by Becker and Kiener in $1955,{ }^{2}$ follows a more benign clinical course, and occurs at a frequency of around one in 30000 .

DMD has been localised to the $\mathrm{p} 21$ region on the short arm of the $X$ chromosome, initially from observations of several girls with the disease who had de novo balanced $\mathrm{X}$; autosome translocations involving this region. ${ }^{3}$ Recently, linkage was confirmed to two cloned DNA sequences, L1.28 and $\mathrm{RC} 8$, which flank this region. ${ }^{4} \mathrm{BMD}$ has also been provisionally localised to this region by linkage to these same sequences, suggesting that BMD and DMD may be allelic. ${ }^{5}$ In this study we investigated linkage between DMD, BMD, and another cloned DNA sequence p754 (isolated by P L Pearson and his colleagues), which detects an RFLP with the restriction enzyme PstI. Twenty informative kindreds were analysed, 14 with DMD and six with BMD.

Six DMD families and four BMD families were informative for both p754 and L1.28; the latter has previously been assigned linkage distances of $17 \mathrm{cM}$

Received for publication 5 December 1984. Accepted for publication 11 January 1985. proximal to the DMD locus ${ }^{4}$ and $19 \mathrm{cM}$ proximal to the BMD locus. ${ }^{5}$ These families were analysed for recombination between these probe loci to determine their order relative to the disease loci.

\section{Materials and methods}

ORIGIN OF PROBES

The $\mathrm{X}$ chromosome single copy sequence $\mathrm{p} 754$ was isolated by $\mathrm{P}$ L Pearson and colleagues and cloned into plasmid pAT153. It has been localised proximal to the DMD locus using rodent-human cell hybrids made from a female with DMD resulting from an $\mathrm{X} ; 21$ translocation. This translocation has a breakpoint on the $\mathrm{X}$ chromosome at or near the Duchenne gene. ${ }^{6}$ Sequence p754 detects a polymorphism with the restriction enzyme PstI and the frequency of the rarer allele in the British population is 0.39 .

L1.28 was selected as a single copy sequence from a library of random human genomic DNA and cloned into plasmid pBR322. It has been localised proximal to the disease loci, between Xp11.0 and

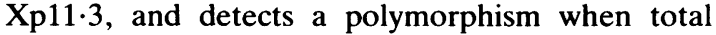
human DNA is cut with TaqI. The frequency of the rarer allele in the normal British population is $0 \cdot 30 .^{5}$

\section{SUBJECTS}

Families in which DMD and BMD had occurred in at least two males and which followed an X linked pattern of inheritance were studied, thus excluding isolated cases possibly arising by new mutation. 
Only those females who were obligatory carriers, together with affected and unaffected males, were used in these studies.

PREPARATION AND ANALYSIS OF DNA

Total human DNA was extracted from whole blood in EDTA by the method of Kunkel et al. ${ }^{7}$ DNA samples of $3 \mu \mathrm{g}$ were digested to completion using the appropriate restriction enzyme (PstI or TaqI).

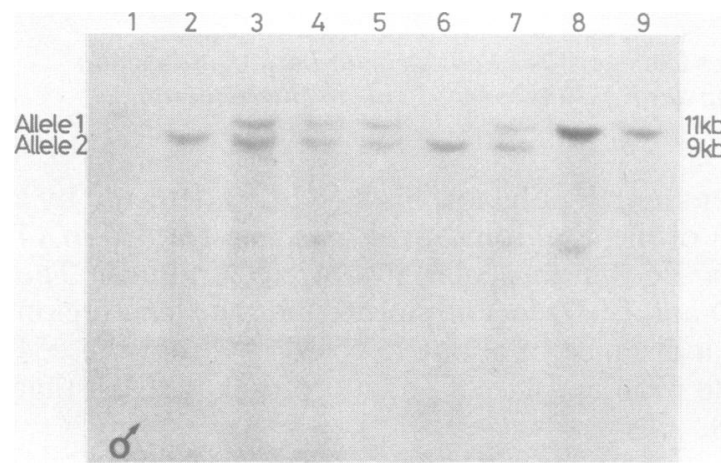

FIG 1 Sequence 754 variants detected by PstI restriction enzyme. The membrane was soaked in $10 \times S S C$ for 20 minutes before blotting and DNA transfer was carried out in $10 \times S S C$. Hybridisation was at $65^{\circ}$ overnight in $10 \mathrm{ml}$ $5 \times S S C, 10 \times$ Denhardts, $0.5 \mathrm{mg} / \mathrm{ml}$ denatured herring sperm DNA, $5 \%$ dextran sulphate, and $50 \mathrm{mmol} / \mathrm{l}$ potassium phosphate (pH 6.5). Hybridisation was overnight at $65^{\circ} \mathrm{C}$ in $10 \mathrm{ml} 5 \times S S C, 2 \times$ Denhardts, $100 \mu \mathrm{g} / \mathrm{ml}$ denatured herring sperm DNA, $10 \%$ dextran sulphate, $20 \mathrm{mmol} / \mathrm{l}$ potassium phosphate ( $\mathrm{pH} 6.5$ ), and the radiolabelled probe. Post-hybridisation washes were at $65^{\circ} \mathrm{C}$ in $3 \times S S C$ plus $0.1 \% S D S$ for 10 to 15 minutes. Autoradiography onto Fuji $x$-ray film and intensifying screen was at $-70^{\circ} \mathrm{C}$ for 1 to 5 days.

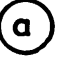

1

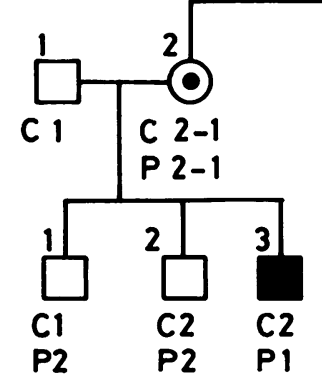

III

P2 P2 P1
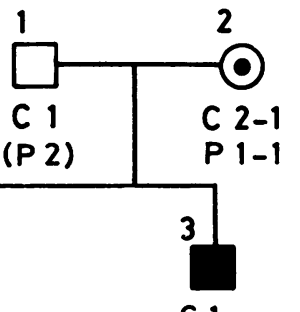

C 1

P 1
The DNA fragments were separated according to molecular weight by electrophoresis on a $0.8 \%$ agarose gel. Blotting of the DNA onto Zetaprobe membrane (Biorad) was carried out using a protocol based on the method of Southern. ${ }^{8}$ Fig 1 shows the alleles detected by $\mathrm{p} 754$, which are defined by the presence or absence of PstI enzyme recognition sites.

\section{LINKAGE ANALYSIS}

This was carried out using Liped 3, a version of the programme Liped, ${ }^{9}$ which derives Lod scores at intervals of 0.05 recombination fraction $(\theta)$. Recombination frequencies were checked by hand in all the families using the maximum likelihood method. ${ }^{10}$

\section{Results}

Fourteen informative DMD families and six informative BMD families were analysed for linkage to the 754 locus. The Lod scores obtained for the different values of $\theta$ and the number of scored meioses is shown in the table, together with linkage data for 10 families informative for the two DNA polymorphisms, 754 and L1.28.

For DMD-754 the recombination fraction $\theta$ is $0.20(95 \%$ confidence limits of $\theta=0.08-0.42)$ with a maximum Lod score of 1.21. For BMD-754, $\theta=$ $0 \cdot 15(95 \%$ confidence limits of $\theta=0.04-0.33)$ with maximum Lod score 1.661, while for 754-L1.28 $\theta=$ 0.15 with maximum Lod score of $1.668(95 \%$ confidence limits of $\theta=0.03-0.35$ ).

Fig $2 a$ and $b$ shows the segregation of 754 and L1.28 alleles in one DMD kindred and one BMD kindred, where the site of recombination between

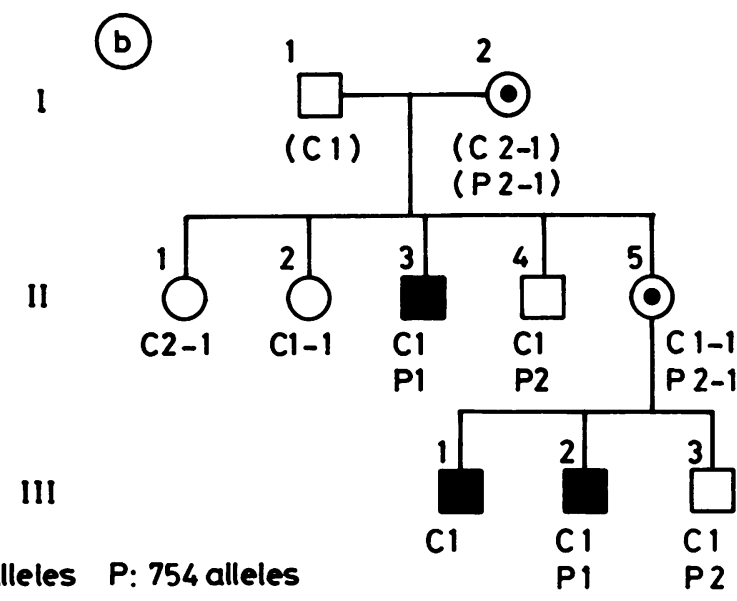

FIG 2 Segregation of 754 and L1.28 alleles in (a) a DMD kindred and (b) a BMD kindred. 
TABLE Lod scores for DMD, BMD, and marker loci.

\begin{tabular}{|c|c|c|c|}
\hline$\theta$ & $\begin{array}{l}D M D-754 \\
(n=14) \\
(x=37)\end{array}$ & $\begin{array}{l}B M D-754 \\
(n=6) \\
(x=27)\end{array}$ & $\begin{array}{l}L . .28-75 . \\
(n=I(1)\end{array}$ \\
\hline 0.01 & $-4 \cdot 303$ & -1.419 & \\
\hline 0.015 & -0.567 & +11.927 & $+1 \cdot 116$ \\
\hline 0.10 & $+0 \cdot 6+2$ & +1.551 & +1.593 \\
\hline (1).15 & $+1 \cdot 087$ & $+1 \cdot 661$ & $+1 \cdot 668$ \\
\hline (1.20) & $+1 \cdot 210$ & +1.552 & +1.566 \\
\hline 0.25 & $+1 \cdot 156$ & +1.327 & +1.368 \\
\hline 0.30 & +0.990 & $+1 \cdot(142$ & $+1 \cdot 1119$ \\
\hline 0.35 & +0.760 & +0.735 & $+(1.819$ \\
\hline 0.40 & +0.501 & $+(1.444$ & +0.517 \\
\hline 0.45 & +0.238 & +0.193 & +0.231 \\
\hline
\end{tabular}

$\theta=$ recombination fraction.

$\mathrm{n}=$ number of informative families.

$\mathrm{x}=$ number of scored meioses.

L1.28 and the disease loci can be identified precisely.

In the BMD kindred, a cross over has occurred between the BMD and L1.28 loci in generation II in subject II.3 or II.4. The probability is that no such cross over has occurred between the BMD and 754 locus. In the DMD kindred there has been a cross over between the DMD and L1.28 loci in generation III in subject III.2. Again, no obvious cross over has occurred between the 754 locus and the disease locus.

\section{Discussion}

The data suggest that neither DMD nor BMD is very closely linked to $\mathrm{p} 754$, but they are consistent with previous results, ${ }^{5}$ placing $\mathrm{BMD}$ in the same region of the $\mathrm{X}$ chromosome as $\mathrm{DMD}$, and suggesting that the two disorders may be allelic.

Evidence from doubly informative families suggests that the 754 and L1.28 loci are approximately $15 \mathrm{cM}$ apart with 754 closer to the DMD and BMD loci, since in the two kindreds shown in fig 2 there have been cross overs between $\mathrm{Ll} .28$ and the disease loci, but not between 754 and these loci. Although in the BMD kindred the phase is not known for 754 , the most likely explanation is that no cross over has occurred beween 754 and BMD.

Despite the fact that 754 does not appear to be closely linked to the DMD and BMD loci it can still be used for the calculation of carrier risks in females from Duchenne and Becker families. Previously, the two probes L1.28 and RC8 have been used for this purpose, in conjunction with pedigree and CK data, ${ }^{11} 12$ and $57 \%$ of women were heterozygous for one or both loci. Sequence 754 has a heterozygote frequency of $48 \%$, so if the three probes are used together, $75 \%$ of women would be heterozygous for at least one locus.

We would like to thank Drs Helen Kingston, Tom O'Brien, Hywel Williams, and our colleagues in other centres for obtaining blood samples, as well as the many families who provided them. We thank Dr Linda Meredith for practical assistance, and D M Katibeh for computer data preparation. This work was supported by grants from the Muscular Dystrophy Group of Great Britain and the Muscular Dystrophy Association of America.

\section{References}

1 Emery AEH. In: Rowland LP, ed. Pathogenesis of human muscular dystrophies. International Congress Series No 404. Amsterdam: Excerpta Medica, 1977:42-52.

2 Becker PE, Kiener F. Eine neue X-chromosomale muskeldystrophic. Arch Psychiatr Nervenkr 1955:193:427-48.

' Zatz M. Vianna-Morgante AM. Campos P. Diament AJ. Translocation $(X: 6)$ in a female with Duchenne muscular dvstrophy: implications for the localisation of the DMD locus. $J$ Med Genet 1981:18:442-7.

+ Davies KE. Pearson PL. Harper PS, et al. Linkage analysis of two cloned DNA sequences flanking the Duchenne muscular dystrophy locus on the short arm of the human X-chromosome. Nucleic Acids Res 1983:11:2303-12.

5 Kingston HM. Sarfarazi M. Thomas NST, Harper PS. Localisation of the Becker muscular dystrophy gene on the short arm of the X-chromosome by linkage to cloned DNA sequences. Hum Genet 1984:67:6-17

'Worton RG. Duif C. Sylvester JE. Schmickel RD, Huntington FW. Duchenne muscular dystrophy involving translocation of the dind gene next to ribosomal RNA genes. Science 1984:224:1447-9.

7 Kunkel LM. Smith KD, Boyer SH, et al. Analysis of human Y-chromosome-specific reiterated DNA in chromosome variants. Proc Natl Acad Sci USA 1977;74:1245-9.

* Southern EM. Detection of specific sequences among DNA fragments separated by gel electrophoresis. J Mol Biol 1975:98:503-17.

"Ott J. Estimation of the recombination fraction in human pedigrees: efficient computation of the likelihood for human linkage studies. Am J Hum Genet 1974:26:588-97.

11 Emery AEH. Methodology in medical genetics. An introduction to statistical methods. Edinburgh. London: Churchill Livingstonc, 1976

1 Harper PS, O'Brien T. Murray JM, Davies KE, Pearson P, Williamson $R$. The use of linked DNA polymorphisms for genotype prediction in families with Duchenne muscular dystrophy. J Med Genet 1983;20:252-4.

12 Kingston HM. Sarfarazi M. Newcombe R, Willis N, Harper PS. Carrier detection in Becker muscular dystrophy using creatine kinase estimation and DNA analysis. Clin Genet (in press).

Correspondence and requests for reprints to Professor P S Harper, Section of Medical Genetics, University of Wales College of Medicine, Heath Park, Cardiff CF4 $4 \mathrm{XN}$. 